\title{
A Study on Emotional Intelligence and Vocational Self-Esteem
}

\author{
Ayhan Babaroğlu \\ University of Hitit, Institude of Health \\ Department of Child Development/ Turkey \\ Levent Sangün \\ University of Cukurova Adana Vocational High School/ Turkey
}

\begin{abstract}
The aim of this study was to investigate the relationship between vocational selfesteem and emotional intelligence. A total of 390 (188 women and 202 men) university students volunteered to participate in the study were included. Bar-On Emotional Quotient Inventory and Vocational Self-Esteem Scale as well as General Information Form were used to collect the data. As a result of the study, a positive and significant relationship was found between emotional intelligence and vocational self-esteem. This positive and significant relationship was also found for subscales of emotional intelligence. In addition, a positive and significant relationship was found between emotional intelligence and vocational self-esteem in terms of gender and the value processes don't take place in emotional intelligence, men's professional self-esteem level is as twice as women's vocational self-esteem level at the beginning, the increase in the vocational self-esteem level is greater in women when emotional intelligence is included in the process.
\end{abstract}

Keywords: Emotional Intelligence; Professional Self-esteem; Vocational self-esteem; University Student

\section{INTRODUCTION}

Salovey and Mayer [1990] have defined emotional intelligence as a sub-form of social intelligence that involves the ability to monitor one's own and others' feelings and emotions, to discriminate among them and to use this information to guide one's thinking and action. Daniel Goleman [1995] has defined emotional intelligence as the capability to recognize their own and other people's emotions, and to evaluate and manage them. Goleman has reported that emotional intelligence is very important, that a successful life required emotional intelligence [EQ] rather than standard intelligence [IQ] and that the absence of emotional intelligence could lead to negative impacts in numerous fields from family life to vocational success and from social relations to health conditions [Goleman, 1998].

As it is the case in other fields, lack or inefficiency of emotional intelligence will appear in the vocational field also. Vocation can be defined as the activities that require creative power, which are carried out continuously by the individual for subsistence [Nazlı, 2011]. Vocation selection holds a very important place in the selections made by an individual throughout one's life. Because in a sense, individuals determine their future life when selecting their vocation. Vocation has reflections on shaping of the personality in the individual's life and on sociopsychological basis. For this reason, individual must take their characteristics into consideration when selecting their vocation. One must evaluate the vocations that are open to them and select a vocation that has maximum favorable aspects and minimum negative aspects in terms of one's requirements [Kuzgun, 1983]. A vocation that is not compatible with the 
personality characteristic can be problematic for the individual. Super and Crities [1963] stated that individuals between 12-24 years of age, which is called "investigation period", try to clarify their career path by examining one or more profession areas and reduce the number of options by observing professions and their levels in general.

Profession selection, which holds a very important place among the selections made by an individual during one's lifetime, is a reflection to and expression in a profession of the selfconcept, formed through a development process as a result of interaction between the individual and the environment [Nazll, 2011]. Professional self-esteem is a component of general self-concept. Self concept is the integration of one's own image with all explanations related how one's perceives one's self [Super, Starishevsky, Matlin \& Jordaan, 1963]. Selfesteem is the degree of how much one is valuable in the world [Lingren, 1991]. According to Horney [1994], every person is born with a unique potential and self-esteem is derived from this potential self-confidence. Although self-concept has characteristics that differentiate one from the others, self-esteem is related with how one perceives one's self when one assesses these characteristics. When explaining self-concept, Super [1953] has also explained the concept of professional self-esteem, which is related with the professional aspect of self, and defined professional self-esteem as a judgment of worthiness, established by the individual regarding the self-concept acquisitions accepted by the individual regarding the profession, notwithstanding whether it has been converted into a professional preference or not. Professional self-respect concept develops in line with the concepts of self concept and selfesteem, and is an expression of the self-concept in terms of profession [Arıcak, 2007].

Various definitions of vocational self-esteem can be found in the examination of the researches in this field. Tabassum, Ali and Bibi [2011] have stated that vocation constitutes the whole of life and have defined vocational self-esteem as the degree of one's vocational value feeling required for the individual to be successful in one's work branch. According to Kunes-Connell [1991], it refers to a role identity which is consistent within the vocation and compatible with the expectations of the establishment. Zieff [1995] stated that it is the competence level of the individual related with his/her work area. Cornel [1997] defined vocational self-esteem as the negative or positive personal attitude of a person related with one's vocational competence, performance and value. Professional self-esteem of the individual may present one's professional position and assumptions related with one's professional role within the framework of personal self-concept understanding. In this context, emotional intelligence constitutes a corner-stone in numerous fields such as coping, leadership, self-development, improvement etc. Emotional intelligence has supportive characteristics in the fields of feeling good, making friends, social competence and self-esteem [Mayer, et al., 2004; Zeidner et al., 2009; Joseph \& Newman, 2010].

Changes in social structure, differentiation of economic conditions, developments and changes in the family structure and work circles result in the individuals establishing communication with higher number people and different people, compared to the past. This condition imposes intense roles on the individuals in different conditions and scenarios. Fulfillment of these roles with required competence affects work, home and private life completely. This is the point where the importance of emotional intelligence comes to light. Goleman [1998] has mentioned awareness and evaluation of emotions and knowing one's limits when defining emotional intelligence. Persons, who are aware of their emotions when they are formed, can make more sound decisions about their lives. Failure in noticing actual emotions leaves the person at the mercy of the respective emotion. People, who develop this awareness, start to develop their environments afterwards. Awareness on how emotions affect and direct the behaviors 
constitutes the basis of emotional competences. Emotional intelligence holds an important place in having the targeted performance in work life and in private life, not permitting passionate feelings takeover the ego, continuing motivation, approaching the feelings in the environment with empathy and having social skills related with work life, including those that are significant in terms of teamwork. Thus, it would not be wrong to expect that individuals with a high emotional intelligence will also have a high vocational self-esteem. Because, these individuals can establish connections easily with the people around them, read and manage their reactions, feelings intelligently, and overcome the potential problems that may occur. Again, these people are natural leaders, they can express common ideas that are not uttered and can use this effectively to guide a community towards its targets. Naturally, these people are people who are wanted and sought people in social life and the work life circles. Because, they are emotionally nutritive and can motivate people positively [Goleman, 1999].Considering the earlier studies in the literature, emotions are considered to be an integral part of organizational life and therefore it is emphasized that more attention should be given to the mood of the individuals in business life [Ashforth \& Humprey, 1995]. Strong impact of selfesteem on thoughts, moods and behaviors of individuals caused many negative consequences to be associated with low self-esteem, aggression and antisocial behavior [Donnellan et al., 2005]. There are findings indicating that there is a positive relationship between self-esteem and emotional functions [Lyubomirsky, et al., 2006; Moreno, et al, 2009]. The working environment includes skills of understanding life, thinking and using feelings effectively. There are assumptions suggesting that emotional intelligence affects many variables related to job performance, job satisfaction, absenteeism, commitment and leadership [Gates, 1995; Goleman, 1995; Megerian \& Sosik, 1996; Cooper \& Sawaf, 1997; Carmeli, 2003; Abraham, 2004; Petrides \& Furnham, 2006; Adeyemu, 2007; Iordanoglou, 2007; Salami, 2007; Nadeni \& Sodani, 2010]. These variables are closely related to professional self-esteem of the individual. There are also some findings suggesting that there is a positive relationship between emotional intelligence and professional self-esteem [Creed, et al., 2002; Austin et al., 2007; Smith et al., 2011; Zafarizadeh et al., 2014].

Every person has emotions, but it is not enough to have these emotions. Emotional intelligence allows us to reflect knowledge about emotions and energy of emotions into our daily lives and professions and give appropriate responses to them in addition to recognizing and evaluating emotions of us and other people. Professional self-esteem of an individual demonstrates acceptance for his/her professional role within the framework of his/her professional position and personal self-understanding. Emotional intelligence and professional self-esteem are the areas that are intertwined with each other and affect each other in different dimensions and proportions. Within the framework of the above comments and evaluations, the aim of this study is to determine the relationship between emotional intelligence and professional selfesteem.

\section{Participants}

\section{METHODS}

This study was conducted with a total of 390 volunteer students [188 women, 202 men] who attend different programs of Adana Vocational School of Cukurova University in the 2014-15 academic year. Demographic information of the students participated in the study are presented in Table 1. 


\section{Procedure}

The necessary permits were obtained to conduct the study and Adana Vocational School of Cukurova University students were completely interviewed and students were informed that the study was going to be carried out on a voluntary basis. Then, students participating in the research were informed about Bar-On Emotional Intelligence Scale and Professional SelfEsteem Scale and they were asked to fill out the General Information Form to obtain their demographic information. The necessary disclosures were made when needed.

The Bar-On Emotional Intelligence Scale that we used in the study was subjected to reliability analysis, and as a result of the analysis, the reliability of Bar-On Emotional Intelligence Scale was calculated as 0,59 in the environmental compliance dimension; 0,73 in the stress management dimension and 0,56 in the general mood dimension and it was calculated as 0,94 for Professional Self-Esteem Scale, respectively. Regression analysis was used to determine the percentage of total variance of independent variables and effects of independent variable emotional intelligence and its sub-dimensions on the dependent variable professional selfesteem.

Table 1. Demographic information about sample

\begin{tabular}{|c|c|c|c|c|c|}
\hline \multicolumn{3}{|l|}{ Features } & \multirow[b]{2}{*}{ Social activity status } & \multirow[b]{2}{*}{$\mathrm{N}$} & \multirow[b]{2}{*}{$\%$} \\
\hline Age & $\mathrm{N}$ & $\%$ & & & \\
\hline $18-19$ & 33 & 8,5 & 1-2 times per month & 234 & 60,0 \\
\hline $20-21$ & 296 & 75,9 & 3-4 times per month & 85 & 21,8 \\
\hline $22-23$ & 39 & 10,0 & 5-6 times per month & 27 & 6,9 \\
\hline $24-25$ & 10 & 2,6 & $7>$ & 34 & 8,7 \\
\hline $26>$ & 12 & 3,1 & Nothing & 10 & 2,6 \\
\hline Economic status & & & Attitude of family & & \\
\hline Income less than expanse & 197 & 50,5 & Authoritarian & 157 & 40,3 \\
\hline Income equivalent to expanse & 161 & 41,3 & Democratic & 205 & 52,6 \\
\hline Income more than expanse & 32 & 8,2 & Uninterested & 28 & 7,2 \\
\hline Mothers' education levels & & & Fathers' education levels & & \\
\hline Illiterate & 51 & 13,1 & Illiterate & 8 & 2,1 \\
\hline Primary school & 270 & 69,2 & Primary school & 259 & 66,4 \\
\hline High school and equivalent & 56 & 14,4 & High school and equivalent & 104 & 26,7 \\
\hline University & 13 & 3,3 & University & 19 & 4,9 \\
\hline Gender & & & Family type & & \\
\hline Female & 188 & 48,2 & Nuclear family & 316 & 81,0 \\
\hline Male & 202 & 51,8 & Extended family & 74 & 19,0 \\
\hline Type of high school & & & Department/Programme & & \\
\hline High school(normally) & 12 & 3,1 & Electricity and Energy & 68 & 17,4 \\
\hline Anatolian high school & 4 & 1,0 & Engine & 57 & 14,6 \\
\hline Industrial high school & 134 & 34,4 & Textile Technology & 68 & 17,4 \\
\hline Vocational school for girls & 63 & 16,2 & Computer Technology & 56 & 14,4 \\
\hline Commerce vocational high school & 69 & 17,7 & $\begin{array}{l}\text { Child care and youth } \\
\text { services }\end{array}$ & 66 & 16,9 \\
\hline Multi-program high school & 3 &, 8 & Accounting and practices & 75 & 19,2 \\
\hline Engine vocational high school & 8 & 2,1 & & & \\
\hline Textile vocational high school & 7 & 1,8 & & & \\
\hline $\begin{array}{l}\text { Anatolian vocational high } \\
\text { school(male/ female) }\end{array}$ & 84 & 21,5 & & & \\
\hline Other & 6 & 1,5 & & & \\
\hline
\end{tabular}

\section{Material}

In this study, "Bar-On Emotional Intelligence Scale" and "Professional Self-Esteem Scale" as well as "General Information Form", which was developed to obtain some demographic information of the group included in the study, were used. 


\section{Bar-On Emotional Intelligence Scale}

In the present study, Bar-On EQ [Emotional Intelligence Scale], which was developed by Reuven Bar-On [1997] and adapted into Turkish by Acar [2001], was used. This scale has been used in numerous academic studies so far and it is considered as one of the best scales measuring the emotional intelligence. This scale consists of 88 items measuring 5 dimensions and 15 sub-dimensions. The dimensions of the scale are personal skills, interpersonal skills, adaptability, coping with stress and general mood. Cronbach's alpha reliability coefficient was calculated for reliability studies of the form. As a result of these calculations, Cronbach's Alpha coefficients were found as 92,12 for all dimensions of the form, 83,73 in the personal awareness dimension, 77,87 in interpersonal skills dimension, 65,42 in the adaptation dimension, 73,14 in the stress management dimension and 75,06 in the general mood dimension, respectively [Acar, 2001].

\section{Vocational Self-Esteem Scale}

Vocational Self-Esteem Scale was developed by Arıcak [1999]. It is a likert-type measuring tool used to measure self-esteem attitudes of individuals, who are already occupied, receiving a vocational training or in a career path, aged 17 and above towards a profession. Vocational Self-Esteem Scale consists of 30 items. 14 of these items include negative and the remaining 16 items include positive expressions. The numbers of positive items are 2, 5, 7, 9, 11, 13, 14, 16, 18, 20, 24, 26, 28 and 30; and the numbers of negative items are 1, 3, 4, 6, 8, 10, 12, 15, 17, 19, $21,22,23,25,27$ and 29. In the scale, the responses of participants receive some points as follows: "Completely Agree" 5, "Agree" 4, "Undecided" 3, "Disagree" 2, "Strongly Disagree" 1 in the positive items; and "Completely Agree" 1, "Agree" 2, "Undecided" 3, "Disagree" 4, "Strongly Disagree" 5, respectively. Scores of each item are summed and the total score is calculated. The total score can range between 30 and 150. The reliability of the scale was tested in two ways. First, Cronbach's a reliability coefficient, which is a measure of the internal consistency of the scales and primarily used for Likert-type scales, was calculated. Second, the reliability coefficient obtained by repeating the test. Cronbach's a reliability coefficient of the scale, which was administrated on 152 students and reduced to 30 items by item analyses, was calculated as 0.93 by using SPSS package program [Arıcak, 2001].

\section{RESULTS}

Considering the data given in Table 2, there is a significant and positive relationship between emotional intelligence and vocational self-esteem [F(1-388) $=23.588 ; \mathrm{p}<0.01 ; \mathrm{t}=4.857]$. We also see this positive and significant relationship emotional intelligence and vocational selfesteem sub-dimensions of self awareness $[F(1-388)=20,184 ; p<0,01 ; t=4,493]$, interpersonal relationships $[\mathrm{F}(1-388)=6,279 ; \mathrm{p}<0,05 ; \mathrm{t}=2,506]$, adaptability with conditions and environment $[\mathrm{F}(1-388)=16,253 ; \mathrm{p}<0,01 ; \mathrm{t}=4,032]$, stress management $[\mathrm{F}(1-388)=17,780$; $p<0,01 ; t=4,217]$ and the general $\operatorname{mood}[F(1-388)=9,358 ; p<0,01 ; t=3,059]$. 
Table 2.Regression analysis between dimensions of emotional intelligence and vocational selfesteem

\section{Vocational Self-Esteem}

\begin{tabular}{|c|c|c|c|c|c|}
\hline Emotional Intelligence & B & $\begin{array}{l}\text { Standard } \\
\text { Error } \\
\text { B }\end{array}$ & $\begin{array}{c}\text { Standardized } \\
\text { Coefficients } \\
\beta \\
\end{array}$ & $\mathbf{t}$ & $\mathbf{p}$ \\
\hline Constant & 52,675 & 10,328 & & 5,100 &, 000 \\
\hline $\begin{array}{l}\text { Personal self- awaressness } \\
\mathrm{R}=0.222\end{array}$ & $F(1-388)=20,184^{* *}$ & 2,769 & ,222 & 4,493 &, 000 \\
\hline Constant & 73,581 & 10,120 & & 7,271 &, 000 \\
\hline $\begin{array}{l}\text { Interpersonal relationship } \\
\mathrm{R}=0.126\end{array}$ & $\begin{array}{r}6,138 \\
F(1-388)=6,279^{*}\end{array}$ & 2,450 &, 126 & 2,506 & 013 \\
\hline Constant & 59,355 & 9,848 & & 6,027 & ,000 \\
\hline $\begin{array}{l}\text { Adaptability condition } \\
\text { enviroment } \\
\mathrm{R}=0.201\end{array}$ & $\begin{array}{l}\text { and } 10,739 \\
F(1-388)=16,253^{* *}\end{array}$ & 2,664 & ,201 & 4,032 &, 000 \\
\hline $\begin{array}{l}\text { Constant } \\
\text { Stres management } \\
\mathrm{R}=0.209\end{array}$ & $\begin{array}{c}74,117 \\
7,988 \\
F(1-388)=17,780^{* *} \\
\end{array}$ & $\begin{array}{l}5,969 \\
1,895\end{array}$ & ,209 & $\begin{array}{r}12,417 \\
4,217\end{array}$ & $\begin{array}{l}, 000 \\
, 000\end{array}$ \\
\hline $\begin{array}{l}\text { Constant } \\
\text { General mood } \\
\mathrm{R}=0.153\end{array}$ & $\begin{array}{c}77,499 \\
5,352 \\
\mathrm{~F}(1-388)=9,358^{* *}\end{array}$ & $\begin{array}{l}7,056 \\
1,750\end{array}$ &, 153 & $\begin{array}{r}10,983 \\
3,059\end{array}$ & $\begin{array}{l}, 000 \\
, 002\end{array}$ \\
\hline $\begin{array}{l}\text { Constant } \\
\text { Total } \\
\mathrm{R}=0.239\end{array}$ & $\begin{array}{c}46,186 \\
14,187 \\
\mathrm{~F}(1-388)=23,588^{* *}\end{array}$ & $\begin{array}{r}10,891 \\
2,921\end{array}$ & ,239 & $\begin{array}{l}4,241 \\
4,857\end{array}$ & $\begin{array}{l}, 000 \\
, 000\end{array}$ \\
\hline
\end{tabular}

Table 3 gives us the vocational self-esteem values, which vary with the increase in emotional intelligence, and which are calculated according to the regression equation formed between the points of total emotional intelligence and the subscales, which are presented in the previous table [Table 2], and vocational self-esteem. Examination of the table reveals that at the beginning level, at which emotional intelligence values are not present, the highest vocational self-esteem values are seen in the subscales of general mood [77,499] and stress management $[74,117]$. When values related with emotional intelligence are introduced into the process, while the highest vocational self-esteem values are in the general total [102,934] and stress management [106,069] subscales in an increase of four units, the highest vocational selfesteem values are in the general total $[159,682]$ and self-consciousness $[152,203]$ subscales in an increase of eight units. 
Table 3.The results of the regression equation showing the change in emotional intelligence and occupational self-esteem

\begin{tabular}{|c|c|c|c|c|c|c|}
\hline $\begin{array}{l}\text { An increase } \\
\text { in emotional } \\
\text { intelligence }\end{array}$ & $\begin{array}{c}\text { Personal self- } \\
\text { awaressness } \\
\mathrm{Y}=52,675+ \\
12,441 \mathrm{X}\end{array}$ & $\begin{array}{c}\begin{array}{c}\text { Interpersonal } \\
\text { relationship }\end{array} \\
\mathrm{Y}=73,581+ \\
6,138 \mathrm{X} \\
\end{array}$ & $\begin{array}{c}\text { Adaptability } \\
\text { condition and } \\
\text { enviroment } \\
\mathrm{Y}=59,355+ \\
10,739 \mathrm{X} \\
\end{array}$ & $\begin{array}{c}\text { Stres } \\
\text { management } \\
\mathrm{Y}=74,117+ \\
7,988 \mathrm{X} \\
\end{array}$ & $\begin{array}{c}\begin{array}{c}\text { General } \\
\text { mood }\end{array} \\
\mathrm{Y}=77,499+ \\
5,352 \mathrm{X} \\
\end{array}$ & $\begin{array}{c}\text { Total } \\
\mathrm{Y}=46,186+ \\
14,187 \mathrm{X} \\
\end{array}$ \\
\hline 0 & 52,675 & 73,581 & 59,355 & 74,117 & 77,499 & 46,186 \\
\hline 1 & 65,116 & 79,719 & 70,094 & 82,105 & 82,851 & 60,373 \\
\hline 2 & 77,557 & 85,857 & 80,833 & 90,093 & 88,203 & 74,560 \\
\hline 3 & 89,998 & 91,995 & 91,572 & 98,081 & 93,555 & 88,747 \\
\hline 4 & 102,439 & 98,133 & 102,311 & 106,069 & 98,907 & 102,934 \\
\hline 5 & 114,88 & 104,271 & 113,050 & 114,057 & 104,259 & 117,121 \\
\hline 6 & 127,321 & 110,409 & 123,789 & 122,045 & 109,611 & 131,308 \\
\hline 7 & 139,762 & 116,547 & 134,528 & 130,033 & 114,963 & 145,495 \\
\hline 8 & 152,203 & 122,685 & 145,267 & 138,021 & 120,315 & 159,682 \\
\hline \multicolumn{7}{|c|}{$Y=$ Vocational Self-Esteem } \\
\hline
\end{tabular}

In this study, another parameter we have examined was gender [Table 4]. The positive and significant relationship between emotional intelligence and vocational self-esteem applies to both women $[\mathrm{F}(1-186)=16.788 ; \mathrm{p}<0.01 ; \mathrm{t}=4.097]$ and men $[\mathrm{F}(1-200)=5.978 ; \mathrm{p}<0.05 ; \mathrm{t}=$ 2.445].

Table 4.Regression analysis between emotional intelligence and vocational self-esteem by

\begin{tabular}{|c|c|c|c|c|c|}
\hline Indipendent variables & B & $\begin{array}{c}\text { Standard Error } \\
\text { B }\end{array}$ & $\begin{array}{c}\text { Standardized } \\
\text { Coefficients } \\
\beta\end{array}$ & $\mathrm{t}$ & $\mathrm{p}$ \\
\hline Constant & 32,018 & 17,733 & & 1,806 &, 073 \\
\hline $\begin{array}{l}\text { Total } \\
\text { Female } \\
\mathrm{R}=0.288\end{array}$ & $\begin{array}{c}19,287 \\
F(1-186)=16,788^{* *}\end{array}$ & 4,707 & ,288 & 4,097 &, 000 \\
\hline Constant & 61,684 & 13,142 & & 4,694 &, 000 \\
\hline $\begin{array}{l}\text { Total } \\
\text { Male } \\
\mathrm{R}=0.170\end{array}$ & $\begin{array}{c}8,702 \\
\mathrm{~F}(1-200)=5,978^{*}\end{array}$ & 3,559 & ,170 & 2,445 &, 015 \\
\hline
\end{tabular}

Values showing the changes in vocational self-esteem with the increase in emotional intelligence, which is calculated according to the regression equation established between the emotional intelligence points in Table 2 and Table 4 and vocational self-esteem, are shown in Table 5 .

In Table 5, according to the vocational self-esteem values calculated from regression equations, in the absence of contribution of emotional intelligence, professional self-esteem values of men $[61,884]$ are found to be almost twice the vocational self-esteem values of women $[32,028]$. Thus, in the initial phase, where values of emotional intelligence are not taken into consideration, vocational self-esteem values of men are higher compared to women. However, when emotional intelligence values are added; it is observed that vocational self-esteem values of women increase; when their emotional intelligence levels were increased by three units, vocational self-esteem values of men $[87,990]$, women $[89,889]$ and total values $[88,747]$ 
become almost equal; and when their emotional intelligence levels were increased by six units, vocational self-esteem values of women reach the highest value [the highest value that can be obtained from Vocational Self-Esteem scale is 147,750].

Table 5.According to total points and sex; the results of the regression equation showing the increase in emotional intelligence and the change in vocational self-esteem

\begin{tabular}{cccc}
\hline $\begin{array}{c}\text { An increase in } \\
\text { emotional } \\
\text { intelligence }\end{array}$ & $\mathrm{Y}_{\text {Female }}=19,287 \mathrm{x}+32,028$ & $\mathrm{Y}_{\text {Male }}=8,702 \mathrm{x}+61,884$ & $\mathrm{Y}_{\text {Total }}=14,187 \mathrm{x}+46,186$ \\
\hline 0 & 32,028 & 61,884 & 46,186 \\
\hline 1 & 51,315 & 70,586 & 60,373 \\
\hline 2 & 70,602 & 79,288 & 74,560 \\
\hline 3 & 89,889 & 87,990 & 88,747 \\
\hline 4 & 109,176 & 96,692 & 102,934 \\
\hline 5 & 128,463 & 105,394 & 117,121 \\
\hline 6 & 147,750 & 114,096 & 131,308 \\
\hline \multicolumn{5}{c}{$\boldsymbol{x}=$ Total Emotional Intelligence } \\
\hline \multicolumn{4}{c}{}
\end{tabular}

\section{DISCUSSION AND CONCLUSION}

It has been concluded from this study that the total emotional intelligence points affected the vocational self-esteem significantly in the positive direction and that this significant positive relationship was present in all subscales of emotional intelligence. Moreover, it has been observed that there is a parallel relationship between emotional intelligence and vocational self-esteem. In other words, vocational self-respect increases also with the increase in emotional intelligence [Table 2/3].

Considering the earlier studies conducted on the same subject in the literature, some of our results coincide with the findings of these studies [Creed et al., 2002; Austin et al., 2007; Smith et al., 2011; Zafarizadeh et al., 2014]. Since professional self-esteem may affect emotions, thoughts and behaviors of an individual in regard with his/her vocation, it will help him/her with development and socialization problems. Individuals who are aware of their desires and potential respect and care about themselves and they are more determined in the process of self-realization. Because, they know what they want and how to achieve their desires [Salomi, 2007]. They can express their feelings better and recognize, evaluate, regulate emotions of others and put themselves into others' shoes. The ability of recognizing and understanding emotions is a factor that increases the success in social relationships and especially in job interviews [Hogan \& Roberts, 2000; Lopes et al., 2003]. These individuals are said to be more successful in interpersonal relationships [Anthony et al., 2007; Neiss et al., 2009]. Their skills to cope with stress and there strength are better. These skills are very important for individuals working under intense stress and varying conditions. The professional self-esteem is required for both compliance and success in daily life [Erşan et al., 2009]. Thus, people with high self-esteem are more adaptable to the conditions and the environment and they are more realistic. Their problem solving skills are developed [Traş et al., 2011; Karaca et al., 2013]. Coopersmith [1967], defined the concept of self-esteem as a continuous evaluation of individuals of themselves. Professional self-esteem can be defined as a reflection of this into a profession and it is obvious that emotional intelligence is an important determinant of professional self-esteem. Because realize themselves at some point in their professions and there are strong ties between happiness and them in general. Emotional intelligence increases the quality of life of individuals and consequently increases life satisfaction. According to Edgar Schein [1980], the value of career is a self-concept consisting of self-perceived abilities and capabilities, core values, motives and needs. This combination of specific characteristics of 
people is effective in individuals' career choices. There are several studies that indicate the presence of a significant positive relationship between self-esteem and emotional intelligence [Ciarrochi, et al., 2001; Lyubomisky, et. al., 2006; Heck \& Oudsten, 2008; Moreno, et al., 2009; Rey et al., 2011; Vasconcelos et al., 2012; Cheung et al., 2015].

In the findings of the study related with sex, a positive significant relationship was found between vocational self-esteem and emotional intelligence in both men and women [Table 4]. Moreover, the change in vocational self-esteem with the increase in emotional intelligence, calculated according to the regression equation formed between emotional intelligence and vocational self-esteem, and its relationship with sex have presented interesting outputs [Table 5]. It is seen that at the beginning phase, in which the emotional intelligence is not taken into consideration, the vocational self-esteem values of men are higher than the vocational selfesteem values. However, when values related with emotional intelligence are taken into consideration, a dramatic increase is observed in the vocational self-esteem values of women.

These results obtained are thought to arise from the emotional differences between men and women. Because of these differences, women and men handle and control upcoming events in different ways. This suggests that including values related to emotional intelligence might have increased the value of vocational self-esteem of women.

Vocational self-esteem is a part of self-concept and it is associated with individuals' perceptions regarding how valuable and important they see their professions. Self-esteem is the precondition of adaptation and mental health of an individual, while vocational self-esteem is the precondition of professional compliance and satisfaction [Arıcak \& Dilmaç, 2003]. Because individuals defines themselves in this concept. Vocational self-esteem is a specific term and it is more apparent for individuals who need to receive training for a specific profession or practice their profession. In this regard, emotional intelligence and vocational self-esteem appear to be significantly associated with each other. According to the findings of several studies conducted on self-esteem including emotional intelligence and vocational selfesteem concepts, there is a positive correlation between emotional intelligence levels and vocational self-esteem of women [Ciarrochi, et. al., 2001; Cheung, Cheung \& Tak Hue, 2015].

In general, according to the perception of gender in society and various religious and cultural teachings, women are more prone to the guidance of emotions while perceiving, interpreting and expressing their lives. Therefore, the level of emotional intelligence of women is expected to be higher than emotional intelligence of men. However, different results are seen in studies conducted on emotional intelligence.

In some of these studies, emotional intelligence levels of women are stated to be higher compared to men [Bhosle, 1999; King-King, 1999; Wing \& Love, 2001; Singh, 2002; Gürbüz \& Yüksel, 2008; Tasong et al., 2013], whereas some other studies suggest that emotional intelligence levels of men are higher than emotional intelligence levels of women [Chu, 2002; Morisson et al., 2004; Liphits, Braziler \& Tatar, 2012; Cheung, Cheung \& Tak Hue, 2015]. Furthermore, in some of these studies, there is no difference between opposite genders [Acar, 2002; İşmen, 2004; Doğan et al., 2009; Jenaabadi, 2014]. Although there are studies, which were conducted on self-esteem and gender, suggesting that there is no significant difference between these concepts [Healy et al., 1987; Doğan et al., 2009; Başçiftçi et al., 2010; Karaca et.al., 2013], some others suggest that self-esteem levels of women are higher than self-esteem levels of men [Tosang et al., 2013; Jeneabadi, 2014]. 
It can be suggested that the gender factor may create differences between self-esteem, vocational self-esteem and emotional intelligence due to the effect of upbringing, changing roles of men and women, characteristics of men and women, culture, religious factors and interpersonal sensitivity levels [Zahn-Waxler, Kochanska \& McKnew, 1990; Sığrı, Tabak \& Sağrı, 2010]. Brodi and Hall [2000] said that women are more contentious compared to men in changing their emotional responses and men are more reticent to show their feelings and sometimes they are not even aware of the emotions of themselves and others. Development of self-concept, self-esteem and vocational self-esteem starts from childhood under the influence of many factors including emotional intelligence in particular. Apparently, different roles of men and women in traditional family structure and societal expectations have brought changes and transformation in the world of thought of men and women in the process of being included in the modern world. Individual decision-making mechanisms of well-educated women with a profession are more advanced and this results in higher self-esteem and vocational self-esteem of women [Fidan, 2014].

As a result of this study, it was determined that there is a positive and significant relationship between vocational self-esteem and emotional intelligence and its sub-dimensions. In addition, this positive and significant relationship between vocational self-esteem and emotional intelligence exists both in men and women. Another remarkable result of the study is that in the initial phase, where values of emotional intelligence are not taken into consideration, vocational self-esteem values of men are almost twice the vocational self-esteem values of women. However, when emotional intelligence values are included, vocational self-esteem values of women are observed to be significantly increased. In light of all these findings, vocational self-esteem is about our skills, interests, values and how we integrate them into our lives and it is another way of expressing ourselves. Therefore, emotional intelligence should be noticed in this form of expression. Emotional intelligence is a predictor of an individual's success in both private and business life. In this respect, emotional intelligence is the skill of understanding working environment and life as well as thinking and using emotions effectively. Since emotional intelligence improves with the experiences gained with age, this is the most important evidence showing that it can be developed with training. Thus, emotional intelligence can be improved by educational activities starting from the beginning of educational life and it can be regulated in accordance with different types and dimensions to contribute to the development of emotional intelligence individuals. It is very important to guide individuals to choose the correct career path by considering their interests, abilities and values. Since basic emotional differences between opposite sexes affect team work, formation of group behaviors and productivity of the organizations, they should be taken into account. Therefore, corporate organizations may include programs that develop emotional intelligence and raise awareness on this issue in their systems. The findings of this study should be considered within the limitations of the study. Since findings of the study are limited to the samples included, generalization of the results may be possible by having larger sample groups and addressing the subject from different perspectives.

\section{References}

Abraham, R. [2004]. Emotional competence as antecedent to performance: A contigency framework. Genetic, Social \& General Psychology Monographs. 130[2], 117-143.

Acar, F. T. [2002]. Emotional intelligence and leadership. Erciyes University, Journal of Institute for Social Sciences, 12, 53-68.

Acar, F.T. [2001]. Duygusal zekâ yeteneklerinin göreve yönelik ve insana yönelik liderlik davranışlarıyla ilișkisi: Banka şube müdürleri üzerine bir alan araştırması [Unpublished Doctoral Dissertation]. Istanbul University, Institute of Social Sciences, Istanbul. 
Adeyemu, D.A. [2007]. Emotional intelligence and relationship between job satisfaction and organizational commitment of employee in Public Parastatals in Oyo State, Nigeria. Pakistan Journal of Social Sciences, 4[2], 324330.

Anthony, D.B., Holmes, J.G., \& Wood, J.V. [2007]. Social acceptance and self -esteem: tuning the sociometer to interpersonal value. Journal of Personality and Social Psychology, 92 [6], 1024-1039.

Austin, E.J., Evans, P., Magnus, B., \& O’Hanlon, K. [2007]. Preliminary study of empathy emotional intelligence and examination performance in MBCHB student. Medical Education, 41[7], 684-689.

Arıcak, T. [2007]. The inestigation of Turkish University Student's vocational self-esteem levels within different academic departments. California Association for Counseling and Development Journal, 22, 21-33.

Arıcak, T. [2001]. Development of vocational/professional self-esteem scale and its validity and reliability. 6. National Counseling \& Guidance Congress Book. Ankara: Turkish Counseling and Guidance Association Publications, No: 8, p.29.

Arıcak, O. T. [1999]. Self-esteem and vocational self-esteem enhancement through group counselling [Unpublished Doctoral Dissertation], Marmara University, Istanbul.

Arıcak, O.T., \& Dilmac, B. [2003]. An investigation on self-esteem and vocational self-esteem of counseling and guidance students. Trakya University Journal of Social Science, 3[1], 1-7.

Ashford, B.E., \& Humprey, R.H. [1995]. Emotion in the workplace: a reappraisal. Human Relations, 48[2], 97-125. doi: $10.1177 / 001872679504800201$

Bar-On, R. [1997]. The Bar-On Emotional Quotient Inventory [EQ-i]:A measure of emotional intelligence. Technicals Manual. Toronto, Canada: Multi Health Systems.

Basciftci, F., Ozen, S., \& Doyduk, A. [2010]. Comparison of personality and self-esteem for career at Selcuk University Faculty of Technical Education. e- Journal of New World Sciences Academy, Education Sciences, 5[4], 2198-2205.

Bhosle, S. [1999]. Gender differences in EQ. New Delhi, Sage Publications.

Brody. L. R. \& Hall, J. A. [2000]. Gender, emotion, and expression. In M. Lewis \& J. M. Haviland-Jones [Eds.], Handbook of emotions [2nd ed., pp. 338-449]. New York: Guilford Press.

Carmeli, A. [2003]. The relationship between emotional intelligence and work attitıdes, behavior and outcomes: An examination among senior managers. Journal of Managerial Psyhology, 18[8], 788-813.

Carmel, S. [1997]. The professional self-esteem of physicians scale, structure, properties, and the relationship to work outcomes and life satisfaction. Psychological Reports, 80, 591-602.

Cheung, C.K., Cheung, H.Y., \& Tak-Hue, M. [2015]. Emotional intelligence as a basis for self-esteem in young adults. The Journal of Psychology, 149[1], 63-84. doi: 10.1080/00223980.2013.838540

Chu, J. [2002]. Boys development. Reader's Digest, 94-95.

Ciarrochi, J., Chan, A. Y.C., \& Bajgar, J. [2001]. Measuring emotional intelligence in adolescents. Personality and Individual Differences, 31[7], 1105-1119. doi: 10.1016/j.paid.2012.07.032

Cooper, R.K., \& Sawaf, A. [1997]. Executive EQ: Emotional Intelligence in Leadership and Organizations. New York, Grosset/Putnam.

Coopersmith, S. [1967]. Self-Esteem Inventories. California, Consulting Psychologist Press.

Creed, F., Morgan, R., Fiddler, M., Marshall, S., Guthrie, E., \& House, A. [2002]. Depression and anxiety impair health- related quality of life anda re associated with increased cost in general medical inpatient. Psychosomatics, 43[4], 302-309.

Davies, M., Stankov, L., \& Roberts, R. D. [1998]. Emotional intelligence: in search of an elusive construct. Journal of Personality and Social Psychology, 75[4], 9891015.

Dogan, T., Totan, T., \& Sapmaz, F. [2009]. Self-esteem and social intelligence of university students. The Journal of SAU Education Faculty, 17, 235-247.

Donnellan, M. B., Trzesniewski, K. H., Conger, K. J., \& Conger, R. D. [2007]. A three-wave longitudinal study of selfevaluations during young adulthood. Journal of Research in Personality, 41, 453-472.

doi:10.1016/j.jrp.2006.06.004 
Donnellan, M. B., Trzesniewski, K. H., Robins, R. W., Moffitt, T. E., \& Caspi, A. [2005]. Low self-esteem is related to aggression, antisocial behavior, and delinquency. Psychological Science, 16, 328-335. doi: 10.1111/j.09567976.2005.01535.x

Erşan E.E., Doğan O., \& Doğan S. [2009]. The relationship between self-esteem levels and some sociodemographic characteristics of the students of college of physical education and sports. Journal of Clinical Psychiatry, 12[1], 3542 .

Fidan, F.Z. [2014]. Education and self-respect: reconsruction of women identity through education. The Journal of Academic Social Science, 2[2], 12-17.

Gates, G. [1995]. A review of literature on leadership and emotion: exposing theory, posing questions, and forwarding an agenda. Journal of Leadership Studies, 2[3], 98-110.

Goleman, D.[1995]. Emotional intelligence: The theory in practice. New York, Basic Book.

Goleman, D. [1998]. Emotional Intelligence: Why It can Matter More Than IQ. Bloomsbury Publishing PLC.

Gürbüz, S. \& Yüksel, M. [2008]. Emotional intelligence in workplace:its relation with job performance, job satisfaction, organizational citizenship behavior, and some demographic factors. Doğuş University Journal, 9[2], 174-190.

Iordanoglou, D.[2007]. The teacher as leader: The relationship between emotional intelligence leadership effectiveness, commitment and satisfaction. Journal of Leadership Studies, 1[3], 57-66.

Healy, C.C., Mitchel, J. M., \& Mourton, D.L. [1987]. Age and grade differences in career development among community college students. Review of Higher Education, 10[3], 247- 258.

Heck, G. L. Van \& Oudsten, B. L. [2008]. Emotional intelligence: relationship to stress, health, and well-being. In A. Vingerhoets, I. Nyklicek, \& J. Denollet [Eds.], Emotion regulation. Conceptual and clinical issues [pp. 97-121]. New York, NY: Springer.

Hogan, R. T. \& Roberts, B. W. [2000]. A Socioanalytic perspective on person/environment interaction. In W. B. Walsh, K. H. Craik, \& R. H. Price [Eds.], New directions in person-environment psychology [pp. 1-24] Mahway, NJ: Earlbaum.

Horney, K. [1994]. New Ways in Psychoanalysis [Trans: Selçuk Budak]. 2. Edition, Ankara, Oteki Publishing. Işmen, E. [2004]. The relationshıp between emotional intelligence and family functions. Balikesir University Journal of Social Sciences Institute, 7[11], 55-75

Jenaabadi, H. [2014]. Studying the relation between emotional intelligence and self-esteem with academic achivement. Procedia- Social and Behavioral Sciences, 11[14], 203-206. doi:10.1016/j.sbspro.2013.12.685

Joseph, D.L., \& Newman, D.A. [2010]. Emotional intelligence: an integrative meta- analysis and cascading model. Journal of Applied Psychology, 95[1], 57-78. doi:10.1037/a0017286

Karaca, N.H., Aral, N., \& Karaca, L. [2013]. A study of problem solving skills and self-respect of preschool teachers. Journal of Research in Education and Teaching, 2[3], 67-74.

King King, M. [1999]. Measurement of differences in emotional intelligence of preservice educational leadership students and practicing administrators as measured by the multifactor emotional intelligence scale. Dissertation Abstracts International, 60[3], 606.

Kunes-Connell, M. V. [1991]. Towards an occupational self-esteem model for psychiatric nurses [Unpublished doctoral dissertation]. The University of Nebraska, Lincoln. [Internet-12.03.2012] http://digitalcommons.unl.edu/dissertations/AAI9219

Lingren, H. G. [1991]. Self-esteem in children. Children and Family, 12, 1-3.

Lipshits- Braziler, Y., \& Tatar, M. [2012]. Perceived career barriers and coping among youth in Israel; ethnic and gender differences. Journal of Vocational Behavior, 80[2], 545-554. doi: 10.1016/j.jvb.2011.08.010

Lopes, P.N., Salovey, P., \& Starus, R. [2003]. Emotional intelligence, personality and the perceived quality of social relationship. Personality and Individual Differences, 35[3], 641-658. doi: 10.1016/S0191-8869(02)002242-8

Lyubomirsky, S., Tkach, C., \& DiMatteo, M.R. [2006]. What are the differences between happiness and self-esteem? Social Indicators Research, 78[3], 363-404. doi:10.1007/s11205-005-0213-y 
Martinez-Pons, M. [1997]. The relation of emotional intelligence with selected areas of personal functioning. Imagination, Cognition \& Personality, [17], 3-13.

Mayer, J. D., Salovey, P., \& Caruso, D. [2004]. Models of Emotional Intelligence, Sternberg, R.J.[Ed], Handbook of Intelligence [2nd ed], [pp.396-420], Cambridge: Cambridge University Press.

Megerian, L. E., \& Sosik, J. [1996]. An affair of the heart: emotional intelligence and transformational Leadership. Journal of Leadership Studies, 3[4],31-48.

Moreno, D., Estévez, E., Murgui, S., \& Musitu, G. [2009]. Social reputation and relational violence in adolescents: the role of loneliness, self-esteem and life satisfaction. Psicothema, 21, 537-542.

Morrison, T.G., Kalin, R., \& Morrison, M.A. [2004]. Body-image evaluation and body-image investment among adolescents: A test of sociocultural and social comparison theories. Adolescence, 3[155], 571-592. doi: 10.3325/cmj.2008.2.233

Naderi, N., \& Sodani, M. [2010]. The effect of training of interpersonal skills of emotional intelligence on job satisfaction and organizational commitment in employees on industrial company. Advences in Business- Related Scientific Research Journal[ABSRJ], 1[2], 109-118.

Nazlı, S. [2011]. Developmental Guidance Program[4. Edition]. Ankara, Anı Publishing.

Neiss, M.B., Stevenson, J., Legrand, L.N., Lacono, W.G., \& Sedikides, C. [2009]. Self-esteem, negative emotionality, and depression as a common temperamental core: A study of mid-adolescent twin girls. Journal of Personality, 77[2], 327-346. doi:10.1111/j.467-6494.2008.00549.x

Petrides, K.V., \& Furham, A. [2006]. The role of trait emotional intelligence in a gender- specific model of organizational variables. Journal of Applied Social Psychology, 36[2], 552-569.

Rey, L., Extremera, N., \& Pena., M. [2011]. Perceived emotional intellgence, self-esteem and life satisfaction in adolescents. Psychological Intervention, 20[2], 227-234.

Salomi, O.S. [2007]. Relationships of emotional intelligence and self-efficacy to work attitudes among secondary school teachers in southwestern Nigeria. Pakistan Journal of Social Sciences, 4[4],540-547.

Salovey, P.,\& Mayer, J.D. [1990]. Emotional intelligence. Imagination,Cognition and Personality, 9[3], $185-211$.

Schein, E. H. [1980]. Organizational Psychology. Englewood Cliffs, New Jarsey, Prentice- Hall Inc.

Sığrı, U., Tabak, A., \& Sağır, A. [2010]. Acomparison of guilty and shame emotions of workers in terms of genderage differences and shame management in organizations. Cumhuriyet University Journal of Economics and Administrative Sciences, 11[1], 71-85.

Singh, D. [2002]. Emotional intelligence at work: A professional guide. Sage Publications, New Delhi.

Smith, P., Cowie, H., \& Blades, M. [2011]. Understanding children's development[Fifth edition]. West Sussex, John Wiley \& Sons Ltd.

Super, D. E., Starishevsky, R., Matlin, N. \& Jordaan, J. P. [1963]. Career development: self-concept theory. College Extrance Examination Board: NewYork.

Super, D.E. [1953]. A theory of vocational development. American Psychologist. 8[5], 185-190. doi: $10.1037 / \mathrm{h} 0056046$

Tabassum, F., Ali, M. \& Bibi, F. [2011]. Comparison of professional self-esteem of public and private teachers. International Journal of Humanities and Social Science, 1[18], 301-304.

Tosang, M.A., Maleki, H., Ahmadimehr, Z., Hariri, M., \& Shooshtari, M. [2013]. Relationships between self-esteem with emotional intelligence and marital satisfaction among women. World of Sciences Journal, 1[11], 123-130.

Wing, E., \& Love, G.D. [2001]. Elective affinities and uninvited agonies: Mapping emotions with significant others onto health. Emotion, Social Relationships and Health Series in Affective Science.Oxford University Press, New York

Traş, Z., Arslan, C., \& Mentiş Taş, A. [2011]. Analysis of humor styles, problem solving and self-esteem of prospective teachers. International Journal of Human Sciences, 8[2], 716-732.

Vasconcelaos-Ropaso, J., Fernandes, H.M., Teixeira, C.M., \& Bertelli, R. [2012]. Factorial validity and invarience of the Rosenberg Self-Esteem Scale among Portuguese yougsters. Social Indicators Research, 105[3], 483-498. doi: $10.1177 / 1073191112465768$ 
Yuksel, M. [2006]. The relationship between emotional intelligence and performance[an analysis on managers], [Unpublished doctoral dissertation]. Atatürk University, Institute of Social Sciences, Erzurum

Zafarizadeh, A., Baygi, M.E., Tork, M., Soleimany, S., Saidye, F., \& Hosnijeh, A.H.S. [2014]. Examining of the relationship between emotional intelligence and career self-concept in the first year of secondary school male students. Reef Resources Assessment and Management Technical Paper, 40[4], 213-216.

Zahn-Waxler., Kochanska, C., Kruprick, J., \& McKnew, D. [1990]. Patterns of guilty in children of depressed and well mothers. Developmental Psychology, 26[1], 51-59. doi: 10.1037/0012-1649.26.1.51

Zeidner, M., Matthews, G., \& Roberts, R.D. [2009]. What we know about emotional intelligence: how it affects learning, work, relationships, and our mental health. Cambridge, MA: MIT Press.

Zieff, H. E. [1995]. The effect of experiences in clinical training on the Professional self-esteem of clinical psychology students [Unpublished doctoral dissertation], University of Massachusetts, ABD. [Internet-26.04.2012] www.sagepub.com/zieff/pmn.pdf 